\title{
Enhancement of the antitumor activity of ionising radiation by nimotuzumab, a humanised monoclonal antibody to the epidermal growth factor receptor, in non-small cell lung cancer cell lines of differing epidermal growth factor receptor status
}

\author{
Y Akashi', I Okamoto*,', T Iwasa', T Yoshida', M Suzuki', E Hatashita', Y Yamada', T Satoh', M Fukuoka', \\ K Ono ${ }^{2}$ and K Nakagawa'
}

'Department of Medical Oncology, Kinki University School of Medicine, 377-2 Ohno-higashi, Osaka-Sayama, Osaka 589-85 I I, Japan; ${ }^{2}$ Radiation Oncology Research Laboratory, Research Reactor Institute, Kyoto University, 2- 1010 Asashiro-nishi, Kumatori-cho, Sennan-gun, Osaka 590-0494, Japan

\begin{abstract}
The expression and activity of the epidermal growth factor receptor (EGFR) are determinants of radiosensitivity in several tumour types, including non-small cell lung cancer (NSCLC). However, little is known of whether genetic alterations of EGFR in NSCLC cells affect the therapeutic response to monoclonal antibodies (mAbs) to EGFR in combination with radiation. We examined the effects of nimotuzumab, a humanised mAb to EGFR, in combination with ionising radiation on human NSCLC cell lines of differing EGFR status. Flow cytometry revealed that $\mathrm{H} 292$ and $\mathrm{Ma}-\mathrm{I}$ cells expressed high and moderate levels of EGFR on the cell surface, respectively, whereas H460, HI299, and HI975 cells showed a low level of surface EGFR expression. Immunoblot analysis revealed that EGFR phosphorylation was inhibited by nimotuzumab in H292 and Ma-I cells but not in H460, HI299, or HI975 cells. Nimotuzumab augmented the cytotoxic effect of radiation in H292 and Ma-I cells in a clonogenic assay in vitro, with a dose enhancement factor of I.5 and I.3, respectively. It also enhanced the antitumor effect of radiation on H292 and Ma-I cell xenografts in nude mice, with an enhancement factor of 1.3 and 4.0, respectively. Nimotuzumab did not affect the radioresponse of $\mathrm{H} 460$ cells in vitro or in vivo. Nimotuzumab enhanced the antitumor efficacy of radiation in certain human NSCLC cell lines in vitro and in vivo. This effect may be related to the level of EGFR expression on the cell surface rather than to EGFR mutation.
\end{abstract}

British Journal of Cancer (2008) 98, 749-755. doi: I0.1038/sj.bjc.6604222 www.bjcancer.com

Published online 5 February 2008

(c) 2008 Cancer Research UK

Keywords: epidermal growth factor receptor; non-small cell lung cancer; nimotuzumab; monoclonal antibody; genetic alteration; radiosensitisation

Epidermal growth factor receptor (EGFR) is a receptor tyrosine kinase that is abnormally upregulated and activated in a variety of tumours (Baselga, 2002). Deregulation of receptor tyrosine kinases as a result of overexpression or activating mutations is frequently associated with human cancers and leads to the promotion of cell proliferation or migration, inhibition of cell death, or the induction of angiogenesis (Gschwind et al, 2004). The epidermal growth factor receptor has thus been identified as an important target in cancer therapy (Baselga and Arteaga, 2005). Several agents, including small-molecule inhibitors of the tyrosine kinase activity of EGFR (EGFR-TKIs) and monoclonal antibodies (mAbs) specific for EGFR, have been designed to block EGFR signalling selectively (Ettinger, 2006; Harari and Huang, 2006; Imai and Takaoka, 2006). Among EGFR-TKIs, gefitinib and erlotinib have been extensively evaluated in non-small cell lung cancer (NSCLC),

*Correspondence: Dr I Okamoto;

E-mail: chi-okamoto@dotd.med.kindai.ac.jp

Revised 20 November 2007; accepted 7 January 2008; published online 5 February 2008 and sensitivity to these drugs has been associated with the presence of somatic mutations in the EGFR kinase domain or with EGFR amplification (Lynch et al, 2004; Paez et al, 2004; Pao et al, 2004; Cappuzzo et al, 2005; Mitsudomi et al, 2005; Takano et al, 2005). Various mAbs to EGFR are also undergoing preclinical and clinical trials of their efficacy as anticancer agents. However, biological markers able to predict the response to such antibodies have remained elusive.

The possibility of combining chemotherapy or radiation therapy with anti-EGFR mAb treatment has generated much interest, because the cellular targets for these agents and their mechanisms of action are different (Baumann and Krause, 2004). Studies have thus been undertaken to determine whether inhibition of EGFR signalling improves the response to chemotherapy or radiation therapy. Preclinical studies have shown that the anti-EGFR mAb cetuximab markedly increases the cytotoxic effect of chemotherapy or radiation therapy in various EGFR-expressing tumour cell lines (Huang et al, 1999; Milas et al, 2000; Buchsbaum et al, 2002; Prewett et al, 2002; Raben et al, 2005; Ettinger, 2006). A phase III clinical trial also showed that the combination of cetuximab with 
radiation therapy resulted in a significant improvement in local control and survival compared with radiation therapy alone, without an increase in radiation-induced side effects, in patients with locally advanced head and neck cancer (Bonner et al, 2006).

Nimotuzumab (also known as h-R3) is a humanised anti-EGFR $\mathrm{mAb}$, which is currently undergoing clinical evaluation. In a preclinical study, nimotuzumab showed marked antiproliferative, proapoptotic, and antiangiogenic effects in tumours that overexpress EGFR (Crombet-Ramos et al, 2002). In early clinical trials, nimotuzumab has shown a longer half-life and a greater area under the curve (AUC) in comparison with other anti-EGFR antibodies (Crombet et al, 2003). A phase I/II trial showed that nimotuzumab was well tolerated and enhanced the curative potential of radiation in patients with advanced head and neck cancer (Crombet et al, 2004). Given that little is known of the antitumor action of nimotuzumab in NSCLC, we investigated the growth-inhibitory effects of this $\mathrm{mAb}$ alone and in combination with radiation in NSCLC cell lines with differing patterns of EGFR expression. We also examined whether genetic alterations of $E G F R$ affect the antitumor action of combined treatment with nimotuzumab and radiation.

\section{MATERIALS AND METHODS}

\section{Cell lines and reagents}

The human NSCLC cell lines NCI-H292 (H292), NCI-H460 (H460), Ma-1, NCI-H1299 (H1299), and NCI-H1975 (H1975) were obtained as previously described (Okabe et al, 2007) and were maintained under a humidified atmosphere of $5 \% \mathrm{CO}_{2}$ in air at $37.0^{\circ} \mathrm{C}$ in RPMI 1640 medium (Sigma, St Louis, MO, USA) supplemented with $10 \%$ fetal bovine serum and $1 \%$ penicillin-streptomycin. Nimotuzumab was provided by Daiichi Sankyo Co Ltd (Tokyo, Japan), and gefitinib was obtained from AstraZeneca (Macclesfield, UK).

\section{Flow cytometric analysis of surface EGFR expression}

Cells $\left(1.0 \times 10^{6}\right)$ were stained for $2 \mathrm{~h}$ at $4^{\circ} \mathrm{C}$ with an R-phycoerythrin-conjugated $\mathrm{mAb}$ to EGFR (BD Biosciences, San Jose, CA, USA) or an isotype-matched control mAb (BD Biosciences). The cells were washed three times before measurement of fluorescence with a flow cytometer (FACScalibur; Becton Dickinson, San Jose, CA, USA).

\section{Immunoblot analysis}

Cell lysates were fractionated by SDS-polyacrylamide gel electrophoresis on a $7.5 \%$ gel, and the separated proteins were transferred to a nitrocellulose membrane. After blocking of nonspecific sites, the membrane was incubated consecutively with primary and secondary antibodies, and immune complexes were detected with the use of enhanced chemiluminescence reagents, as described previously (Okabe et al, 2007). Primary antibodies to phosphorylated EGFR (pY1068) were obtained from Cell Signaling Technology (Beverly, MA, USA), and those to EGFR were from Zymed (South San Francisco, CA, USA). Horseradish peroxidase-conjugated goat secondary antibodies were obtained from Amersham Biosciences (Little Chalfont, UK).

\section{Clonogenic assay}

Exponentially growing cells in $25-\mathrm{cm}^{2}$ flasks were harvested by exposure to trypsin and counted. They were diluted serially to appropriate densities and plated in triplicate in $25-\mathrm{cm}^{2}$ flasks containing $10 \mathrm{ml}$ of medium supplemented with $1 \%$ fetal bovine serum in the absence or presence of $700 \mathrm{~nm}$ nimotuzumab. After incubation for $24 \mathrm{~h}$, the cells were exposed to various doses of $\gamma$-radiation with a ${ }^{60} \mathrm{Co}$ irradiator at a rate of approximately $0.82 \mathrm{~Gy} \mathrm{~min}^{-1}$ and at room temperature. The cells were then washed with phosphate-buffered saline, cultured in drug-free medium for 10-14 days, fixed with methanol:acetic acid $(10: 1$, $\mathrm{v} / \mathrm{v}$ ), and stained with crystal violet. Colonies containing $>50$ cells were counted. The surviving fraction was calculated as (mean number of colonies)/(number of inoculated cells $\times$ plating efficiency). Plating efficiency was defined as the mean number of colonies divided by the number of inoculated cells for control cultures not exposed to nimotuzumab or radiation. The surviving fraction for combined treatment was corrected by that for nimotuzumab treatment alone. The dose enhancement factor was then calculated as the dose (Gy) of radiation that yielded a surviving fraction of 0.5 for vehicle-treated cells divided by that for nimotuzumab-treated cells (after correction for drug toxicity).

\section{Antitumor activity of nimotuzumab with or without radiation in vivo}

Animal experiments were performed in accordance with the Recommendations for Handling of Laboratory Animals for Biomedical Research, compiled by the Committee on Safety and Ethical Handling Regulations for Laboratory Animal Experiments, Kyoto University, and they met the requirements of the UKCCCR guidelines (Workman et al, 1998). Tumour cells $\left(2 \times 10^{6}\right)$ were injected subcutaneously into the right hind leg of 7 -week-old female athymic nude mice. tumour volume was determined from caliper measurement of tumour length $(L)$ and width $(W)$ according to the formula $L W^{2} / 2$. Treatment was initiated when tumours in each group achieved an average volume of approximately $170-200 \mathrm{~mm}^{3}$. Treatment groups consisted of control, nimotuzumab alone, radiation alone, and the combination of nimotuzumab and radiation, with each group containing seven or eight mice. Nimotuzumab was administered intraperitoneally in a single dose of $1.0 \mathrm{mg}$ per mouse; mice in the control and radiationalone groups were injected with vehicle (physiological saline). Tumours in the right hind leg of mice were exposed to $10 \mathrm{~Gy}$ of $\gamma$-radiation with a ${ }^{60} \mathrm{Co}$ irradiator at a rate of approximately $0.32 \mathrm{~Gy} \mathrm{~min}^{-1}$ beginning $6 \mathrm{~h}$ after drug treatment. Growth delay (GD) was calculated as the time required for treated tumours to achieve a fivefold increase in volume minus the corresponding time required for control tumours. The enhancement factor was then determined as $\left(\mathrm{GD}_{\text {combination }}-\mathrm{GD}_{\text {nimotuzumab }}\right) /\left(\mathrm{GD}_{\text {radiation }}\right)$.

\section{RESULTS}

\section{Surface EGFR expression in NSCLC cell lines of differing EGFR status}

We first examined the surface expression of EGFR in five NSCLC cell lines by flow cytometry. The EGFR status for the cell lines was determined in our previous study (Okabe et al, 2007). Three cell lines (H460, H292, and H1299) possess wild-type EGFR alleles, whereas the other two cell lines (Ma-1 and H1975) harbour EGFR mutations (Table 1). Ma-1 cells have an in-frame deletion in

Table I Characteristics of NSCLC cell lines

\begin{tabular}{lll}
\hline Cell line & EGFR surface expression & EGFR status \\
\hline H460 & Low & Wild type \\
H292 & High & Wild type \\
HI299 & Low & Wild type \\
Ma-I & Moderate & del(E746-A750) \\
H1975 & Low & L858R/T790M \\
\hline
\end{tabular}

EGFR = epidermal growth factor receptor; NSCLC = non-small cell lung cancer 
exon 19 (E746-A750). H1975 cells harbour the L858R mutation in exon 21 and a secondary mutation in exon 20 (T790M). Activating mutations in exons 19 and 21 are associated with sensitivity to EGFR-TKIs (Lynch et al, 2004; Paez et al, 2004; Pao et al, 2004; Cappuzzo et al, 2005; Mitsudomi et al, 2005; Takano et al, 2005), whereas the T790M mutation contributes to the development of resistance to these drugs (Kobayashi et al, 2005;

A

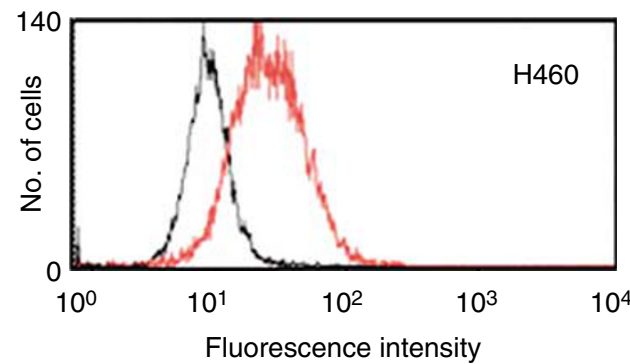

B

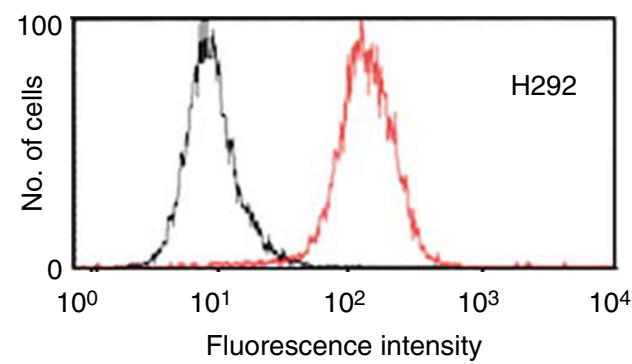

C

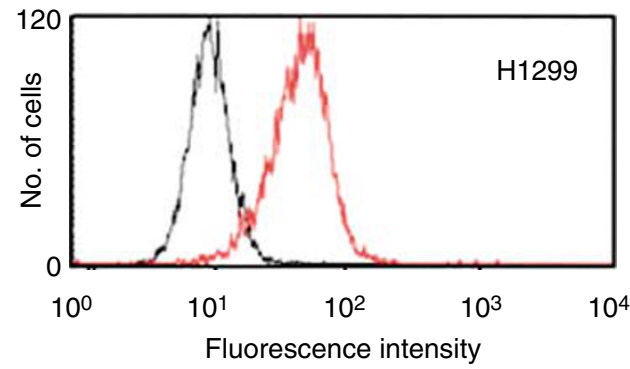

D

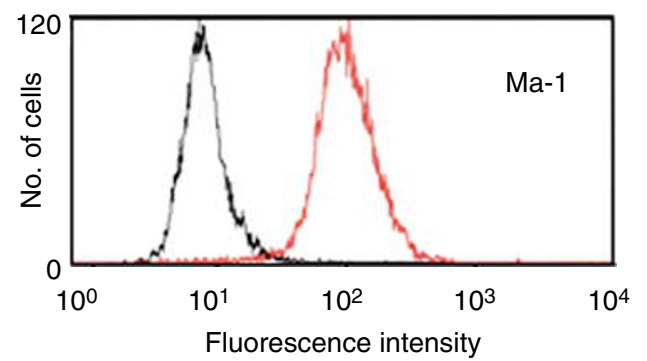

E

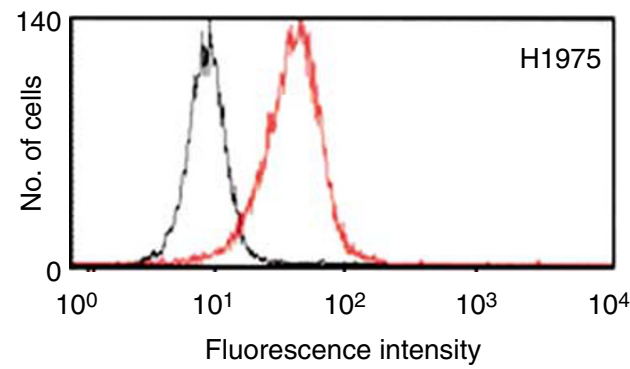

Figure I Expression of EGFR on the surface of NSCLC cells. Surface expression of EGFR on H460 (A), H292 (B), HI299 (C), Ma-I (D), and HI975 (E) cells was determined by flow cytometry. Representative histograms of cells stained with an anti-EGFR mAb (red peak) or with an isotype-matched control mAb (black peak) are shown.
Pao et al, 2005). Our flow cytometric analysis demonstrated that H292 and Ma-1 cells express high and moderate levels of EGFR on the cell surface, respectively, whereas H460, H1299, and H1975 cells showed a low level of surface EGFR expression (Figure 1).

\section{Effect of nimotuzumab on EGFR phosphorylation}

Next, we determined whether nimotuzumab inhibits ligandinduced EGFR phosphorylation in the five NSCLC cell lines. The cells were deprived of serum overnight, exposed to various concentrations of nimotuzumab, or to gefitinib, for $15 \mathrm{~min}$, and then stimulated with EGF for $15 \mathrm{~min}$. In the NSCLC cells that harbour wild-type EGFR (H460, H292, and H1299), phosphorylation of EGFR was undetectable in the absence of EGF, but was markedly induced on exposure of the cells to this growth factor. The EGF-induced phosphorylation of EGFR in these cells was completely inhibited by the EGFR-TKI gefitinib. Nimotuzumab also inhibited the EGF-induced EGFR phosphorylation in a concentration-dependent manner in $\mathrm{H} 292$ cells (which have a high level of surface EGFR expression), whereas it did not substantially affect such phosphorylation in H460 or H1299 cells (both of which have a low level of surface EGFR expression) (Figure 2A-C). We previously showed that the basal level of EGFR phosphorylation was increased in the EGFR mutant NSCLC cell lines Ma-1 and H1975, indicative of constitutive activation of the EGFR tyrosine kinase (Okabe et al, 2007). The phosphorylation of EGFR in EGF-treated Ma-1 cells (which have a moderate level of surface EGFR expression) was inhibited by gefitinib as well as by nimotuzumab in a concentration-dependent manner (Figure 2D). In contrast, the constitutive activation of EGFR in H1975 cells (which have a low level of surface EGFR expression) was inhibited partially by gefitinib but was unaffected by nimotuzumab (Figure 2E). These results suggested that the inhibition of EGFR phosphorylation by nimotuzumab may be related to the surface expression level of EGFR rather than to the mutational status of EGFR

Augmentation of the cytotoxic effect of radiation in NSCLC cells by nimotuzumab in vitro

We examined whether nimotuzumab might enhance the anticancer effect of $\gamma$-radiation in the five NSCLC cell lines with the use of a clonogenic assay. Tumour cells were incubated with or without nimotuzumab for $24 \mathrm{~h}$, exposed to various doses of $\gamma$-radiation, and then allowed to form colonies in drug-free medium for 10-14 days. Survival curves revealed that, whereas nimotuzumab had no effect on the radiation sensitivity of $\mathrm{H} 460, \mathrm{H} 1299$, or H1975 cells, it enhanced the cytotoxic effect of radiation in H292 and Ma-1 cells, with a dose enhancement factor of 1.5 and 1.3, respectively (Figure 3). These results showed that nimotuzumab increased the radiosensitivity of the NSCLC cell lines with high or moderate levels of surface EGFR expression, consistent with the inhibitory effects of this antibody on EGFR signalling.

\section{Augmentation of the antitumor effect of radiation in NSCLC cells by nimotuzumab in vivo}

To determine whether the nimotuzumab-induced potentiation of the response of NSCLC cells to radiation observed in vitro might also be apparent in vivo, we injected three of the cell lines into nude mice to elicit the formation of solid tumours. The mice were then treated with nimotuzumab, radiation, or both modalities. In the H460 xenograft model, tumour growth was inhibited by radiation alone but not by nimotuzumab alone, and the effect of radiation was not promoted by nimotuzumab (Figure 4A). In contrast, radiation and nimotuzumab each inhibited the growth of tumours formed by H292 (Figure 4B) or Ma-1 (Figure 4C) cells during the first few weeks after treatment. Thereafter, the rate of 


\section{A}

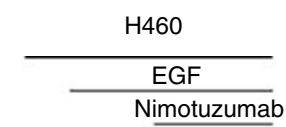

B

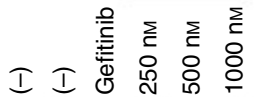

PEGFR

EGFR

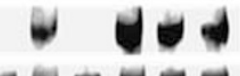

붑 붕
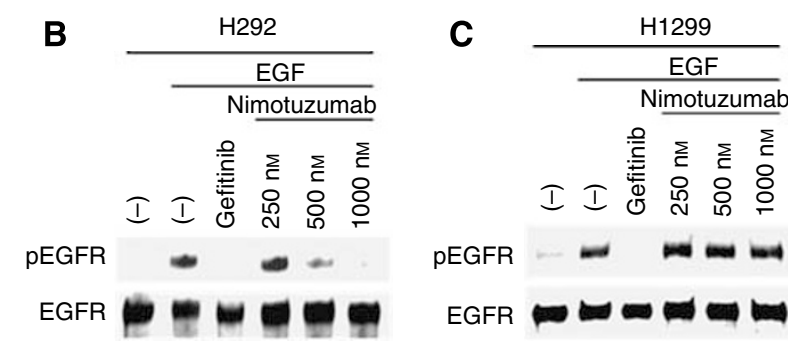

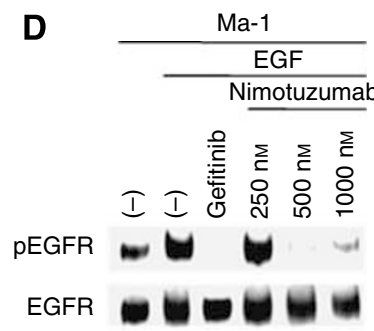

$\mathbf{E}$

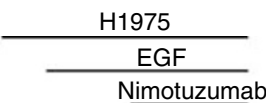

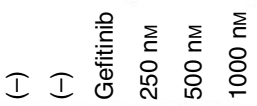

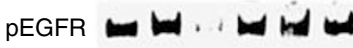

EGFR $\square \square$

Figure 2 Effect of nimotuzumab on EGFR phosphorylation in NSCLC cells. H460 (A), H292 (B), HI299 (C), Ma-I (D), and HI975 (E) cells were deprived of serum overnight and then incubated first for $15 \mathrm{~min}$ in the absence or presence of the indicated concentrations of nimotuzumab or gefitinib $(I 0 \mu \mathrm{M})$ and then for an additional $15 \mathrm{~min}$ in the additional absence or presence of EGF $\left(100 \mathrm{ng} \mathrm{ml}^{-1}\right)$. Cell lysates were then subjected to immunoblot analysis with antibodies to the Tyrl068-phosphorylated form of EGFR (pEGFR) as well as with those to total EGFR.
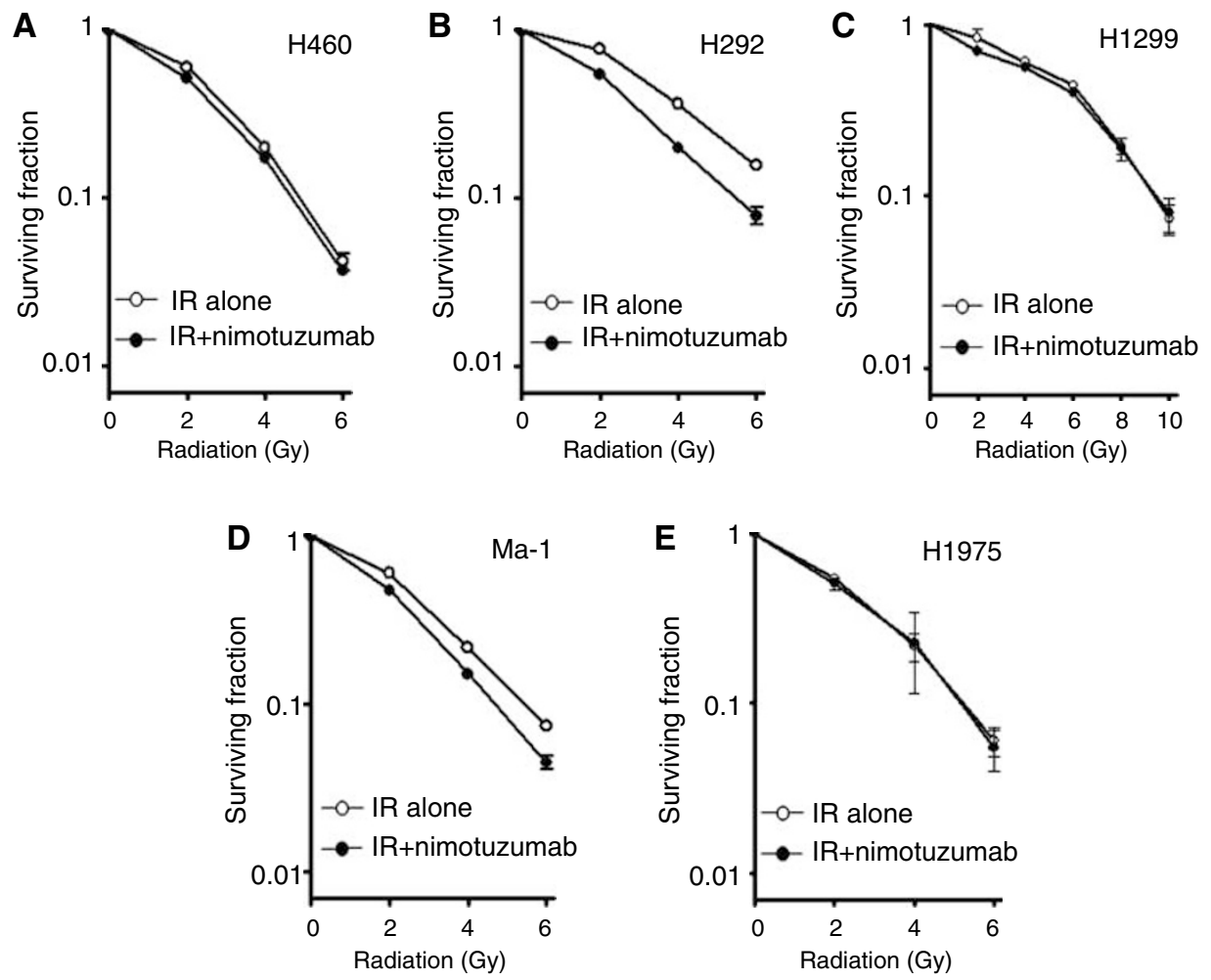

Figure 3 Effect of nimotuzumab on the response of NSCLC cells to radiation in vitro. H460 (A), H292 (B), HI299 (C), Ma-I (D), and HI 975 (E) cells were incubated with or without $700 \mathrm{~nm}$ nimotuzumab in medium supplemented with $1 \%$ fetal bovine serum for $24 \mathrm{~h}$, exposed to the indicated doses of $\gamma$-radiation, and then incubated in drug-free medium supplemented with 10\% serum for 10-14 days for determination of colony-forming ability. Survival curves were generated after correction of colony formation observed for combined treatment with ionising radiation (IR) and nimotuzumab by that apparent for treatment with nimotuzumab alone. Data are means \pm s.d. of triplicates from a representative experiment.

tumour growth increased to a value similar to that seen in control animals. Combined treatment with radiation and nimotuzumab resulted in a substantial delay in tumour growth and subsequent inhibition of the growth rate of $\mathrm{H} 292$ and Ma-1 xenografts. The growth delay after treatment with nimotuzumab alone, radiation alone, or both nimotuzumab and radiation was thus 27.2, 19.6, and 53.6 days, respectively, for $\mathrm{H} 292$ cells and 26.7, 13.0, and 78.3 days, respectively, for Ma-1 cells (Table 2). The enhancement factor for the effect of nimotuzumab on the efficacy of radiation was 1.3 for H292 cells and 4.0 for Ma-1 cells, revealing the effect to be more 

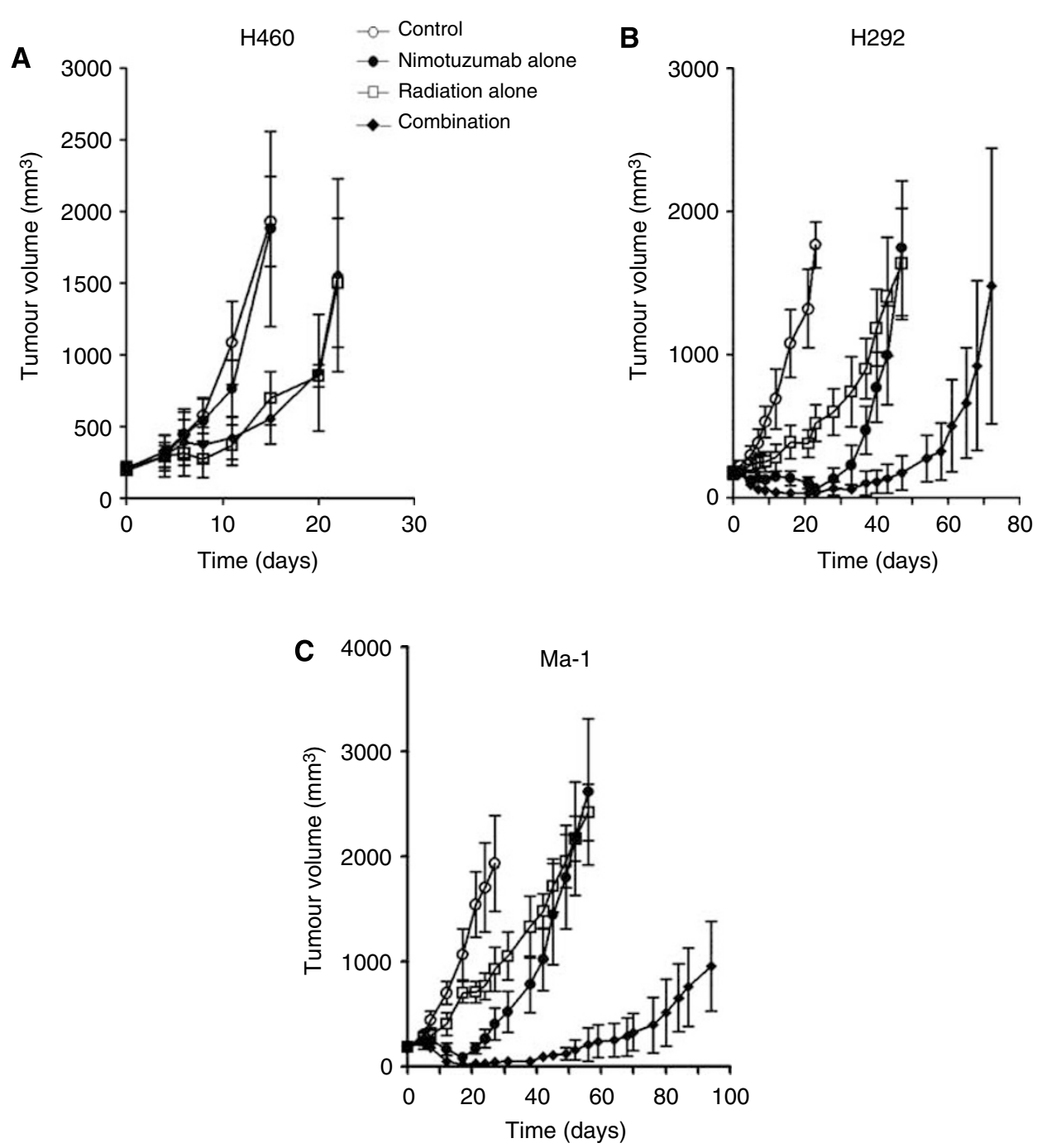

Figure 4 Effect of nimotuzumab on the response of NSCLC cells to radiation in vivo. H460 (A), H292 (B), or Ma-I (C) cells were injected subcutaneously in athymic nude mice. Treatment was initiated when tumours in each group achieved an average volume of approximately $170-200 \mathrm{~mm}^{3}$. Mice were treated with a single dose of nimotuzumab (I.0 mg per mouse) intraperitoneally, a single dose of $\gamma$-radiation ( I $0 \mathrm{~Gy}$ ), or neither (control) or both modalities, and tumour volume was determined at the indicated time points thereafter. Data are means \pm s.d. for seven to eight mice per group.

Table 2 Tumour growth delay in nude mice treated with nimotuzumab, radiation, or both modalities

\begin{tabular}{|c|c|c|c|c|c|c|}
\hline \multirow[b]{2}{*}{ Treatment } & \multicolumn{2}{|c|}{ H460 } & \multicolumn{2}{|c|}{ H292 } & \multicolumn{2}{|c|}{ Ma-I } \\
\hline & Days $^{a}$ & $\mathbf{G D}^{\mathbf{b}}$ & Days & GD & Days & GD \\
\hline Control & 10.4 & & 13.2 & & I5.| & \\
\hline Nimotuzumab alone & 11.8 & 1.4 & 40.4 & 27.2 & 41.8 & 26.7 \\
\hline Radiation alone & 20.4 & 10.0 & 32.8 & 19.6 & 28.1 & 13.0 \\
\hline Nimotuzumab+radiation & 20.5 & 10.1 & 66.8 & 53.6 & 93.4 & 78.3 \\
\hline Enhancement factor & \multicolumn{2}{|c|}{0.86} & \multicolumn{2}{|c|}{1.3} & \multicolumn{2}{|c|}{4.0} \\
\hline
\end{tabular}

$\mathrm{GD}=$ growth delay ${ }^{\mathrm{a}}$ Time required for xenografts in each group to achieve a fivefold increase in volume. ${ }^{\text {b}}$ The additional time (days) required for xenografts in each treatment group to achieve a fivefold increase in volume relative to the corresponding time for xenografts in the control group.

than additive. No pronounced tissue damage or toxicities such as diarrhoea or a decrease in body weight of $>10 \%$ were observed in mice in any of the four treatment groups. These results thus suggested that nimotuzumab potentiated the antitumor activity of radiation in $\mathrm{H} 292$ and Ma-1 cells in vivo as well as in vitro.

\section{DISCUSSION}

Somatic mutations in the EGFR kinase domain and EGFR amplification have been associated with a better response to EGFR-TKIs, such as gefitinib and erlotinib, in patients with NSCLC (Lynch et al, 2004; Paez et al, 2004; Pao et al, 2004; Cappuzzo et al, 2005; Mitsudomi et al, 2005; Takano et al, 2005). Given that little is known of the relation between such EGFR alterations and the response to treatment with anti-EGFR mAbs, we investigated the antitumor effect of combined treatment with the anti-EGFR $\mathrm{mAb}$ nimotuzumab and radiation in NSCLC cell lines of differing EGFR status.

The antitumor effect of EGFR-specific mAbs has been thought to result from inhibition of ligand binding to EGFR and consequent inhibition of EGFR activation (Li et al, 2005; Marshall, 2006). We, therefore, examined the effect of nimotuzumab on EGF-dependent EGFR signalling. Nimotuzumab inhibited the EGF-induced or constitutive phosphorylation of EGFR in H292 and Ma-1 cells (with high and moderate levels of surface EGFR expression, respectively), consistent with the mode of action of this antibody. However, nimotuzumab did not block EGF-induced or constitutive EGFR phosphorylation in H460, H1299, or H1975 cells (all with a 
low level of surface EGFR expression). These observations suggest that the inhibitory effect of nimotuzumab on EGFR signalling depends on the expression level of EGFR on the cell surface. A clonogenic cell survival assay revealed that nimotuzumab enhanced the cytotoxic effect of radiation in $\mathrm{H} 292$ and Ma-1 cells, but not that in H460, H1299, or H1975 cells. These findings support the notion that the inhibition of EGFR signalling by nimotuzumab is responsible, at least in part, for the enhancement of the cytotoxic effect of radiation by this antibody. Irradiation of tumour cells has been shown to activate EGFR via ligand-independent and liganddependent mechanisms, possibly accounting for radiation-induced acceleration of tumour cell repopulation and the development of radioresistance (Schmidt-Ullrich et al, 1997, 2003; Dent et al, 2003). Such radiation-induced activation of EGFR-dependent processes may represent a rationale for combined treatment with radiation and EGFR inhibitors. It remains to be determined whether nimotuzumab is able to block radiation-induced activation of EGFR.

Consistent with our in vitro results, we found that nimotuzumab enhanced the antitumor effect of radiation on H292 or Ma-1 cells in nude mice. Such enhancement was not apparent for tumours formed by $\mathrm{H} 460$ cells. Nimotuzumab alone also manifested a substantial antitumor effect for xenografts formed by H292 or Ma-1 cells but not for those formed by H460 cells. Together these results suggest that the efficacy of nimotuzumab monotherapy is a prerequisite for augmentation of radioresponse by this $\mathrm{mAb}$. Nimotuzumab was previously shown to induce the regression of A431 tumour xenografts in vivo as a result of inhibition of both tumour cell proliferation and tumour angiogenesis (Crombet-Ramos et al, 2002). Immunohistochemical analysis of tumour specimens from head and neck cancer patients treated with the combination of nimotuzumab and radiation also showed evidence of antiproliferative and antiangiogenic effects (Crombet et al, 2004). These observations suggest that effects of nimotuzumab on both NSCLC cell proliferation and tumour angiogenesis might contribute to the enhancement of the antitumor efficacy of radiation by this antibody observed in the present study. Enhancement of the anticancer effect of radiation by the anti-EGFR mAb cetuximab was previously shown to be increased by transfection of cells to upregulate the level of EGFR expression, suggesting that potentiation of the antitumor efficacy of radiation by anti-EGFR mAbs is related to the absolute level of EGFR expression (Liang et al, 2003; Bonner et al, 2004). This finding is consistent with our present results showing that potentiation of the antitumor activity of radiation by nimotuzumab was related to the level of surface EGFR expression. The nimotuzumab-resistant cell line $\mathrm{H} 460$ harbours a mutant form of KRAS (Balko et al, 2006) that has been associated with resistance to cetuximab (Lievre et al, 2006). However, we found that nimotuzumab also failed to inhibit EGF-induced EGFR phosphorylation and to enhance the cytotoxic effect of radiation in H1299 cells, which harbour wild-type KRAS (Coldren et al, 2006). These observations thus support the notion that a low level of EGFR expression at the cell surface is related to resistance to combined treatment with nimotuzumab and radiation, irrespective of KRAS status.

We demonstrated that nimotuzumab inhibited EGFR phosphorylation and enhanced the antitumor effect of radiation in EGFR mutant Ma-1 cells (with a moderate level of surface EGFR expression) but not in EGFR-mutant H1975 cells (with a low level of surface EGFR expression). Nimotuzumab also potentiated the cytotoxic effect of radiation in $\mathrm{H} 292$ cells, which harbour wild-type EGFR alleles and have a high level of surface EGFR expression. These findings support the notion that EGFR mutation is not the major determining factor for enhancement of the antitumor effect of radiation by nimotuzumab, consistent with previous observations with cetuximab (Barber et al, 2004; Tsuchihashi et al, 2005). However, the mechanisms underlying such enhancement of the antitumor effect of radiation may differ between NSCLC cells harbouring wild-type or mutant EGFR alleles. We and others have previously shown that mutations in the tyrosine kinase domain of EGFR are associated with increased ligand-independent tyrosine kinase activity of EGFR (Lynch et al, 2004) and aberrant EGFR signalling (Amann et al, 2005; Okabe et al, 2007). Given that cellcycle checkpoints activated by ionising radiation are defective in EGFR-mutant NSCLC cell lines (Das et al, 2006), the constitutive activity of EGFR in such cells may result in unchecked DNA synthesis and in apoptosis on exposure to ionising radiation. It is possible that these defects in EGFR-mutant cells affect the enhancement of the antitumor efficacy of radiation by nimotuzumab.

In summary, we have shown that nimotuzumab enhanced the antitumor efficacy of radiation in vitro and in vivo, providing a rationale for future clinical investigations of the therapeutic efficacy of nimotuzumab in combination with radiotherapy. Our data suggest that potentiation of the antitumor activity of radiation by nimotuzumab may be related to the level of EGFR expression at the cell surface rather than to EGFR mutation. The preselection of patients on the basis of genetic factors that predict treatment sensitivity or resistance may thus be required for the combination therapy with nimotuzumab and radiation.

\section{ACKNOWLEDGEMENTS}

We thank S Ono for technical assistance.

\section{REFERENCES}

Amann J, Kalyankrishna S, Massion PP, Ohm JE, Girard L, Shigematsu $\mathrm{H}$ Peyton M, Juroske D, Huang Y, Stuart Salmon J, Kim YH, Pollack JR, Yanagisawa K, Gazdar A, Minna JD, Kurie JM, Carbone DP (2005) Aberrant epidermal growth factor receptor signaling and enhanced sensitivity to EGFR inhibitors in lung cancer. Cancer Res 65: 226-235

Balko JM, Potti A, Saunders C, Stromberg A, Haura EB, Black EP (2006) Gene expression patterns that predict sensitivity to epidermal growth factor receptor tyrosine kinase inhibitors in lung cancer cell lines and human lung tumors. BMC Genomics 7: 289

Barber TD, Vogelstein B, Kinzler KW, Velculescu VE (2004) Somatic mutations of EGFR in colorectal cancers and glioblastomas. $N$ Engl J Med 351: 2883

Baselga J (2002) Why the epidermal growth factor receptor? The rationale for cancer therapy. Oncologist 7(Suppl 4): 2-8

Baselga J, Arteaga CL (2005) Critical update and emerging trends in epidermal growth factor receptor targeting in cancer. J Clin Oncol 23: $2445-2459$
Baumann M, Krause M (2004) Targeting the epidermal growth factor receptor in radiotherapy: radiobiological mechanisms, preclinical and clinical results. Radiother Oncol 72: 257-266

Bonner JA, Buchsbaum DJ, Russo SM, Fiveash JB, Trummell HQ, Curiel DT, Raisch KP (2004) Anti-EGFR-mediated radiosensitization as a result of augmented EGFR expression. Int J Radiat Oncol Biol Phys 59: $2-10$

Bonner JA, Harari PM, Giralt J, Azarnia N, Shin DM, Cohen RB, Jones CU, Sur R, Raben D, Jassem J, Ove R, Kies MS, Baselga J, Youssoufian H, Amellal N, Rowinsky EK, Ang KK (2006) Radiotherapy plus cetuximab for squamous-cell carcinoma of the head and neck. $N$ Engl J Med 354: $567-578$

Buchsbaum DJ, Bonner JA, Grizzle WE, Stackhouse MA, Carpenter M, Hicklin DJ, Bohlen P, Raisch KP (2002) Treatment of pancreatic cancer xenografts with Erbitux (IMC-C225) anti-EGFR antibody, gemcitabine, and radiation. Int J Radiat Oncol Biol Phys 54: 1180-1193 
Cappuzzo F, Hirsch FR, Rossi E, Bartolini S, Ceresoli GL, Bemis L, Haney J, Witta S, Danenberg K, Domenichini I, Ludovini V, Magrini E, Gregorc V, Doglioni C, Sidoni A, Tonato M, Franklin WA, Crino L, Bunn Jr PA, Varella-Garcia M (2005) Epidermal growth factor receptor gene and protein and gefitinib sensitivity in non-small-cell lung cancer. J Natl Cancer Inst 97: 643-655

Coldren CD, Helfrich BA, Witta SE, Sugita M, Lapadat R, Zeng C, Baron A, Franklin WA, Hirsch FR, Geraci MW, Bunn Jr PA (2006) Baseline gene expression predicts sensitivity to gefitinib in non-small cell lung cancer cell lines. Mol Cancer Res 4: 521-528

Crombet T, Osorio M, Cruz T, Roca C, del Castillo R, Mon R, IznagaEscobar N, Figueredo R, Koropatnick J, Renginfo E, Fernandez E, Alvarez D, Torres O, Ramos M, Leonard I, Perez R, Lage A (2004) Use of the humanized anti-epidermal growth factor receptor monoclonal antibody $\mathrm{h}-\mathrm{R} 3$ in combination with radiotherapy in the treatment of locally advanced head and neck cancer patients. J Clin Oncol 22: 1646-1654

Crombet T, Torres L, Neninger E, Catala M, Solano ME, Perera A, Torres O, Iznaga N, Torres F, Perez R, Lage A (2003) Pharmacological evaluation of humanized anti-epidermal growth factor receptor, monoclonal antibody h-R3, in patients with advanced epithelial-derived cancer. J Immunother 26: $139-148$

Crombet-Ramos T, Rak J, Perez R, Viloria-Petit A (2002) Antiproliferative, antiangiogenic and proapoptotic activity of h-R3: a humanized antiEGFR antibody. Int J Cancer 101: 567-575

Das AK, Sato M, Story MD, Peyton M, Graves R, Redpath S, Girard L, Gazdar AF, Shay JW, Minna JD, Nirodi CS (2006) Non-small cell lung cancers with kinase domain mutations in the epidermal growth factor receptor are sensitive to ionizing radiation. Cancer Res 66: 9601-9608

Dent P, Yacoub A, Contessa J, Caron R, Amorino G, Valerie K, Hagan MP, Grant S, Schmidt-Ullrich R (2003) Stress and radiation-induced activation of multiple intracellular signaling pathways. Radiat Res 159: $283-300$

Ettinger DS (2006) Clinical implications of EGFR expression in the development and progression of solid tumors: focus on non-small cell lung cancer. Oncologist 11: 358-373

Gschwind A, Fischer OM, Ullrich A (2004) The discovery of receptor tyrosine kinases: targets for cancer therapy. Nat Rev Cancer 4: $361-370$

Harari PM, Huang S (2006) Radiation combined with EGFR signal inhibitors: head and neck cancer focus. Semin Radiat Oncol 16: 38-44

Huang SM, Bock JM, Harari PM (1999) Epidermal growth factor receptor blockade with C225 modulates proliferation, apoptosis, and radiosensitivity in squamous cell carcinomas of the head and neck. Cancer Res 59: $1935-1940$

Imai K, Takaoka A (2006) Comparing antibody and small-molecule therapies for cancer. Nat Rev Cancer 6: 714-727

Kobayashi S, Boggon TJ, Dayaram T, Janne PA, Kocher O, Meyerson M, Johnson BE, Eck MJ, Tenen DG, Halmos B (2005) EGFR mutation and resistance of non-small-cell lung cancer to gefitinib. $N$ Engl J Med 352: $786-792$

Li S, Schmitz KR, Jeffrey PD, Wiltzius JJ, Kussie P, Ferguson KM (2005) Structural basis for inhibition of the epidermal growth factor receptor by cetuximab. Cancer Cell 7: 301-311

Liang K, Ang KK, Milas L, Hunter N, Fan Z (2003) The epidermal growth factor receptor mediates radioresistance. Int J Radiat Oncol Biol Phys 57: $246-254$

Lievre A, Bachet JB, Le Corre D, Boige V, Landi B, Emile JF, Cote JF, Tomasic G, Penna C, Ducreux M, Rougier P, Penault-Llorca F, LaurentPuig P (2006) KRAS mutation status is predictive of response to cetuximab therapy in colorectal cancer. Cancer Res 66: 3992-3995

Lynch TJ, Bell DW, Sordella R, Gurubhagavatula S, Okimoto RA, Brannigan BW, Harris PL, Haserlat SM, Supko JG, Haluska FG, Louis DN, Christiani DC, Settleman J, Haber DA (2004) Activating mutations in the epidermal growth factor receptor underlying responsiveness of non-small-cell lung cancer to gefitinib. $N$ Engl J Med 350: 2129-2139

Marshall J (2006) Clinical implications of the mechanism of epidermal growth factor receptor inhibitors. Cancer 107: 1207-1218

Milas L, Mason K, Hunter N, Petersen S, Yamakawa M, Ang K, Mendelsohn J, Fan Z (2000) In vivo enhancement of tumor radioresponse by C225 antiepidermal growth factor receptor antibody. Clin Cancer Res 6: $701-708$

Mitsudomi T, Kosaka T, Endoh H, Horio Y, Hida T, Mori S, Hatooka S, Shinoda M, Takahashi T, Yatabe Y (2005) Mutations of the epidermal growth factor receptor gene predict prolonged survival after gefitinib treatment in patients with non-small-cell lung cancer with postoperative recurrence. J Clin Oncol 23: 2513-2520

Okabe T, Okamoto I, Tamura K, Terashima M, Yoshida T, Satoh T, Takada M, Fukuoka M, Nakagawa K (2007) Differential constitutive activation of the epidermal growth factor receptor in non-small cell lung cancer cells bearing EGFR gene mutation and amplification. Cancer Res 67: 2046-2053

Paez JG, Janne PA, Lee JC, Tracy S, Greulich H, Gabriel S, Herman P, Kaye FJ, Lindeman N, Boggon TJ, Naoki K, Sasaki H, Fujii Y, Eck MJ, Sellers WR, Johnson BE, Meyerson M (2004) EGFR mutations in lung cancer: correlation with clinical response to gefitinib therapy. Science 304: $1497-1500$

Pao W, Miller V, Zakowski M, Doherty J, Politi K, Sarkaria I, Singh B, Heelan R, Rusch V, Fulton L, Mardis E, Kupfer D, Wilson R, Kris M, Varmus H (2004) EGF receptor gene mutations are common in lung cancers from 'never smokers' and are associated with sensitivity of tumors to gefitinib and erlotinib. Proc Natl Acad Sci USA 101: $13306-13311$

Pao W, Miller VA, Politi KA, Riely GJ, Somwar R, Zakowski MF, Kris MG, Varmus H (2005) Acquired resistance of lung adenocarcinomas to gefitinib or erlotinib is associated with a second mutation in the EGFR kinase domain. PLoS Med 2: 225-235

Prewett MC, Hooper AT, Bassi R, Ellis LM, Waksal HW, Hicklin DJ (2002) Enhanced antitumor activity of anti-epidermal growth factor receptor monoclonal antibody IMC-C225 in combination with irinotecan (CPT-11) against human colorectal tumor xenografts. Clin Cancer Res 8: $994-1003$

Raben D, Helfrich B, Chan DC, Ciardiello F, Zhao L, Franklin W, Baron AE, Zeng C, Johnson TK, Bunn Jr PA (2005) The effects of cetuximab alone and in combination with radiation and/or chemotherapy in lung cancer. Clin Cancer Res 11: 795-805

Schmidt-Ullrich RK, Contessa JN, Lammering G, Amorino G, Lin PS (2003) ERBB receptor tyrosine kinases and cellular radiation responses. Oncogene 22: $5855-5865$

Schmidt-Ullrich RK, Mikkelsen RB, Dent P, Todd DG, Valerie K, Kavanagh BD, Contessa JN, Rorrer WK, Chen PB (1997) Radiation-induced proliferation of the human A431 squamous carcinoma cells is dependent on EGFR tyrosine phosphorylation. Oncogene 15: 1191-1197

Takano T, Ohe Y, Sakamoto H, Tsuta K, Matsuno Y, Tateishi U, Yamamoto S, Nokihara H, Yamamoto N, Sekine I, Kunitoh H, Shibata T, Sakiyama $\mathrm{T}$, Yoshida T, Tamura T (2005) Epidermal growth factor receptor gene mutations and increased copy numbers predict gefitinib sensitivity in patients with recurrent non-small-cell lung cancer. J Clin Oncol 23: $6829-6837$

Tsuchihashi Z, Khambata-Ford S, Hanna N, Janne PA (2005) Responsiveness to cetuximab without mutations in EGFR. $N$ Engl $J$ Med 353: $208-209$

Workman P, Twentyman P, Balkwill F, Balmain A, Chaplin D, Double J, Embleton J, Newell D, Raymond R, Stables J, Stephens T, Wallace J (1998) United Kingdom Co-ordinating Committee on Cancer Research (UKCCCR) Guidelines for the Welfare of Animals in Experimental Neoplasia 2nd edn. Br J Cancer 77: 1-10 